\title{
Structural and Electrical Properties of Ammonium Thiocyanate Doped Poly Ethylene Oxide / Poly Vinyl Pyrrolidone Blend Polymer Electrolytes
}

\author{
M. Muthuvinayagam, K. Sundaramahalingam, D. Vanitha, M. Vahini
}

\begin{abstract}
Blend polymer electrolytes based on PEO:PVP with various wt\% of $\mathrm{NH}_{4} \mathrm{SCN}$ are prepared by simple solution casting method. The prepared polymer electrolytes are characterized using several techniques. The XRD studies confirm the amorphous and crystalline behavior of prepared BPEs. Functional groups present in the systems are confirmed by Fourier Transform Infrared spectroscopy (FTIR) studies. The electrical properties are analyzed by ac impedance technique. The maximum ionic conductivity is obtained for $20 w t \%$ of ammonium thiocyanate doped system and it is $1.81 \times 10^{-5} \mathrm{~S} / \mathrm{cm}^{-1}$. The dielectric properties of polymer films are also studied and discussed.
\end{abstract}

Keywords : XRD, FTIR, AC Impedance, PEO:PVP, Dielectric analysis

\section{INTRODUCTION}

In modern Life, polymer electrolytes are very important in batteries for the rapid development of portable electronic devices. Polymer electrolyte batteries have high energy density, high specific capacity [1-3]. Proton conducting polymer electrolytes are mostly considered because of their large applications in fuel cells and electro-chromic devices [4-7]. Several authors are working with proton conducting polymer electrolytes based on synthetic and Bio polymers [8-11].

At room temperature, $\mathrm{PEO}$ is semi crystalline nature. At high temperature, the conductivity of PEO is $\sim 10^{-3} \mathrm{~S} / \mathrm{cm}$. PVP has more amorphous nature at room temperature. PVP is a conjugated polymer with excellent properties, thermal conductivity, environmental stability [12, 13]. Polymer blending is one of the techniques to improve the conductivity and electrochemical stability of BPEs. In 2011, K. Kiran kumar et al reported that PEO - PVP - NaF polymer

Revised Manuscript Received on December 09, 2019.

* Correspondence Author

M. Muthuvinayagam*, Department of Physics, Kalasalingam Academy of Research and Education, Anand nagar, Krishnankoil-626126, tamilnadu, India. Email: mmuthuvinayagam@gmail.com

K. Sundaramahalingam, International Research Centre, Kalasalingam Academy of Research and Education, Anand nagar, Krishnankoil-626126 tamilnadu, India. Email: sundaramahalingam07@gmail.com

D. Vanitha, Department of Physics, Kalasalingam Academy of Research and Education, Anand nagar, Krishnankoil-626126, tamilnadu, India. Email:vanibala2003@gmail.com

M. Vahini, International Research Centre, Kalasalingam Academy of Research and Education, Anand nagar, Krishnankoil-626126 tamilnadu, India. Email: mvahini1991@gmail.com electrolyte has ionic conductivity of $1.17 \times 10^{-7} \mathrm{~S} / \mathrm{cm}$ [14]. In 2015, Sharanappa Chapi et.al reported that, PEO - PVP $\mathrm{CoCl} 2$ Polymer electrolyte has conductivity of $5 \times 10^{-6} \mathrm{~S} / \mathrm{cm}$ [15]. In this work, PEO:PVP polymer blend electrolytes with various wt $\%$ of $\mathrm{NH}_{4} \mathrm{SCN}$ are prepared and further analyzed.

\section{EXPERIMENTAL PROCEDURE}

Polymer electrolytes are prepared with constant ratio of PEO:PVP (30:70) and $\mathrm{x} w \mathrm{w} \%$ of ammonium thiocyanate $(\mathrm{x}=$ 5 - 25). The precursor materials analytical grade polyethylene oxide (PEO), poly vinyl pyrrolidone (PVP) are purchased from Sigma Aldrich., India. Ammonium thiocyanate with $\mathrm{m} . \mathrm{w}=76.122 \mathrm{~g} / \mathrm{mol}$ is purchased from Merck, India. The precursor PEO is dissolved in double distilled water. As well, PVP and ammonium thiocyanate solutions are also stirrer separately. The above three solutions are mixed and stirred 36 hours to become the viscous solution. The viscous solution was then poured in petridish. The flexible transparent films are obtained.

The blend polymer electrolytes are characterized by various approaches. XRD pattern of the BPEs are recorded by Bruker $\mathrm{X}$-Ray diffractometer having $\left(\lambda=1.540 \mathrm{~A}^{\circ}\right)$ in the range of $10^{\circ}-60^{\circ}$. FTIR spectrum of the electrolytes are recorded using "SHIMADZU IR Tracer 100" in 400-4000 $\mathrm{cm}^{-1}$ wave number. The AC impedance analysis are done by HIOKI 3532-50 Hi-tester in the frequency range of $42 \mathrm{~Hz}-1 \mathrm{MHz}$.

\section{RESULTS AND DISCUSSION}

\section{A. XRD Analysis}

Fig. 1 shows the XRD spectra of various composition of ammonium thiocynate doped PEO:PVP BPEs. In XRD Analysis, the parent polymer PEO has peaks at $19^{\circ}$ and $23^{\circ}$. When copolymer PVP is added to PEO, the crystalline peaks are reduced and get only one hump at $20^{\circ}$. After ammonium thiocyanate is added to the polymer electrolyte, the hump at $20^{\circ}$ is still reduced. And also hump at $2 \Theta=28^{\circ}$ is appeared due to addition of ammonium thiocyanate. The maximum hump and peaks are reduced for $20 \mathrm{wt} \%$ of ammonium nitrate added system. 


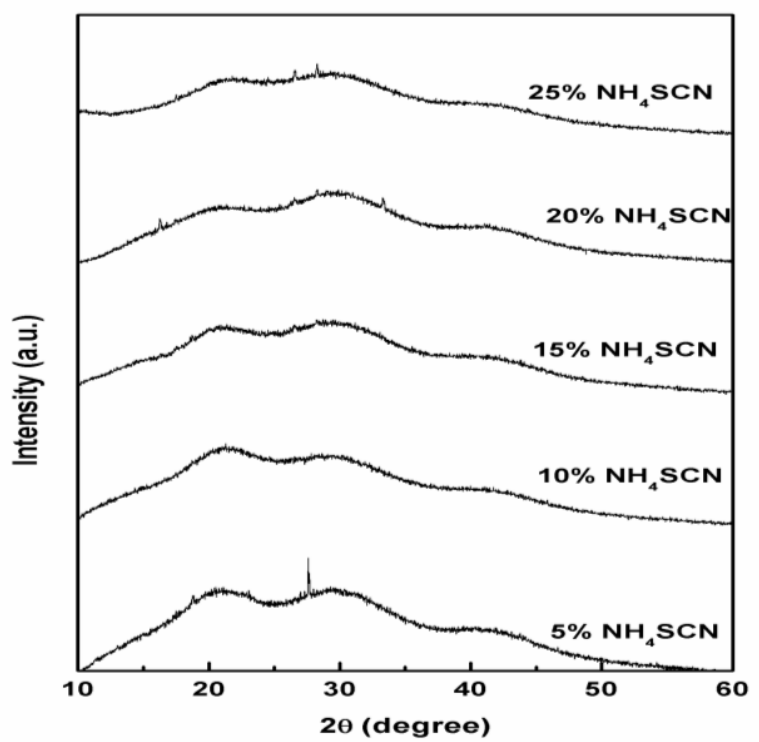

Fig. 1. XRD Pattern for PEO/PVP/ $\mathrm{NH}_{4} \mathrm{SCN}$ polymer electrolytes

B. FTIR analysis

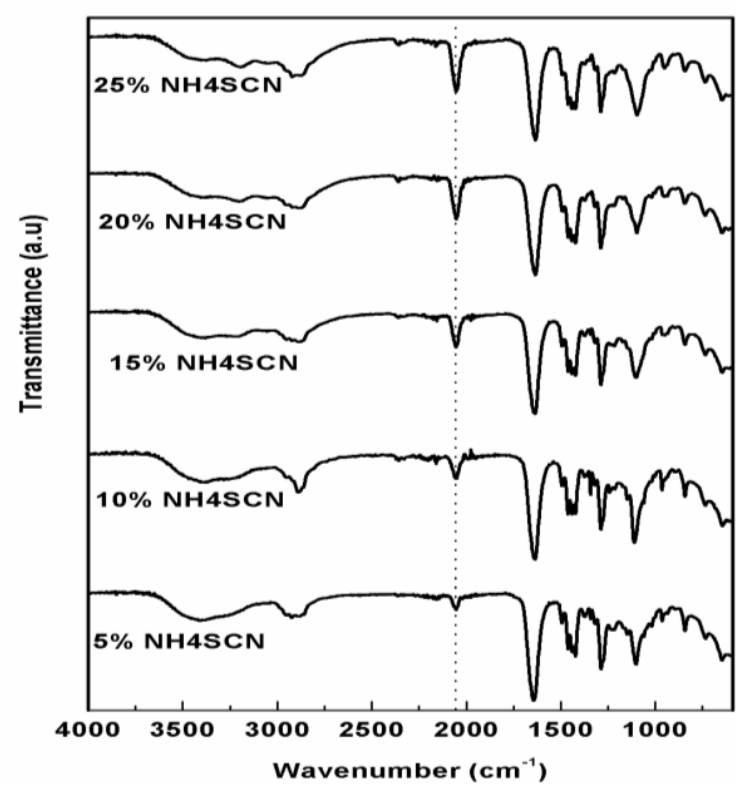

Fig. 2. FTIR Spectra of PEO/PVP/NH ${ }_{4} \mathrm{SCN}$ systems

In the blend polymer electrolytes, there are two possible interactions for the cation at electron rich ether group of $\mathrm{PEO}$ and $\mathrm{C}=\mathrm{O}$ of PVP. By the addition of the salt, the corresponding ion will approach the suitable coordinating site. In the fig. 2 , it is certainly observed that $\mathrm{C}=\mathrm{O}$ displays minor shift and increase in intensity.

The sharp band is decreased in intensity by increasing the concentration of salt. The band noticed at $1461 \mathrm{~cm}^{-1}$ is due to $\mathrm{CH}_{2}$ scissoring mode of polymer PEO. Stretching vibration of $\mathrm{C}-\mathrm{O}$ at $953 \mathrm{~cm}^{-1}$ is due to $\mathrm{PEO}$ with $\mathrm{CH}_{2}$ rocking asymmetric vibration. Vibration bands observed at $1282 \mathrm{~cm}^{-1}, 1348 \mathrm{~cm}^{-1}$, $1461 \mathrm{~cm}^{-1}$ are assigned to $\mathrm{CH}_{2}$ asymmetric twisting, $\mathrm{CH}_{2}$ bending of $\mathrm{PEO}$ and $\mathrm{CH}_{2}$ wagging, respectively. Band at 834 $\mathrm{cm}^{-1}$ is due to $\mathrm{CH}_{2}$ rocking mode of PVP. Absorption band near to $1461 \mathrm{~cm}^{-1}$ due to the $\mathrm{CH}_{2}$ wagging. Likewise, Two strong bands at $1349 \mathrm{~cm}^{-1}$ and $1687 \mathrm{~cm}^{-1}$ which corresponds to the $\mathrm{C}-\mathrm{N}$ stretching and $\mathrm{C}=\mathrm{O}$ stretching, and it confirms the presence of polymer PVP.. From this analysis, it is understood that there is strong complexation between polymers and salt FTIR wave numbers and assignments are tabulated in table I.

Table 1: FTIR Assignments and corresponding wavenumbers

\begin{tabular}{|c|l|c|}
\hline $\begin{array}{l}\text { Wavenumb } \\
\text { er }\end{array}$ & Assignments & Ref. \\
\hline 956 & $\begin{array}{l}\mathrm{CH}_{2} \text { rocking asymmetric } \\
\text { vibration }\end{array}$ & {$[16]$} \\
\hline 1283 & $\mathrm{CH}_{2}$ asymmetric twisting & {$[17,18]$} \\
\hline 1349 & $\mathrm{CH}_{2}$ bending of PEO & {$[19,18]$} \\
\hline 1461 & $\mathrm{CH}_{2}$ scissoring mode of PEO & {$[20]$} \\
\hline 1639 & $\mathrm{C}=\mathrm{O}$ stretching & {$[20]$} \\
\hline 2893 & $\begin{array}{l}\text { asymmetric } \mathrm{CH} \text { stretching of } \\
\mathrm{CH}_{2}\end{array}$ & {$[21]$} \\
\hline
\end{tabular}

\section{AC Impedance analysis Cole-Cole plot}

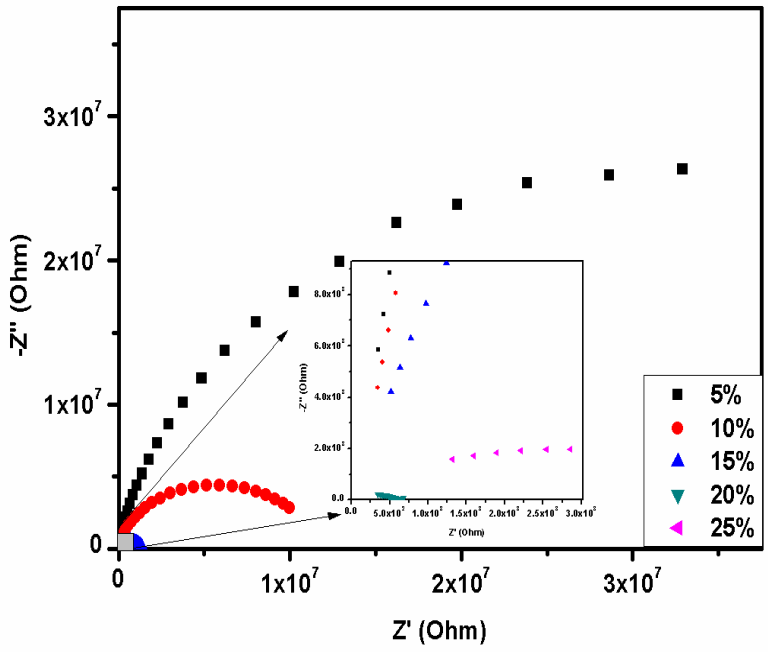

Fig. 3. Cole-Cole plot of PEO:PVP:NH4SCN BPEs.

The impedance plots for $\mathrm{PEO} / \mathrm{PVP} / \mathrm{Xwt} \%$ ammonium thiocyanate $\left(\mathrm{NH}_{4} \mathrm{SCN}\right)$ polymer electrolytes at ambient temperature are shown in Fig. 3. There is one semi-circular portion in all the polymer systems. In the complex impedance representation, the bulk resistance of the films are decreased while increasing the concentration of $\mathrm{NH}_{4} \mathrm{SCN}$, and the maximum bulk resistance reduction at $20 \mathrm{wt} \% \mathrm{NH}_{4} \mathrm{SCN}$ system. The ion migration and the polarization of immobile polymer chains produce the impedance effect from resistance and capacitance which represent the depressed semicircle [22]. Using the following formula to obtain the conductivity of BPEs,

$$
\sigma=1 / R_{b} A
$$

1-thickness of the film, A- area of the film area, B- Rb-Film bulk resistance.

From the following formula, the conductivity is tabulated in table II. 
Table II: Conductivities of prepared PEO-PVP-xwt\% of $\mathrm{NH}_{4} \mathrm{SCN}$ doped blend polymer electrolytes.

\begin{tabular}{|c|c|}
\hline Compositions & Conductivity (S/cm) \\
\hline $\mathrm{PEO} / \mathrm{PVP} / 5 \mathrm{wt} \% \mathrm{NH}_{4} \mathrm{SCN}$ & $2.20 \times 10^{-10}$ \\
\hline $\mathrm{PEO} / \mathrm{PVP} / 10 \mathrm{wt} \% \mathrm{NH}_{4} \mathrm{SCN}$ & $1.03 \times 10^{-9}$ \\
\hline $\mathrm{PEO} / \mathrm{PVP} / 15 \mathrm{wt} \% \mathrm{NH}_{4} \mathrm{SCN}$ & $7.83 \times 10^{-9}$ \\
\hline $\mathrm{PEO} / \mathrm{PVP} / 20 \mathrm{wt} \% \mathrm{NH}_{4} \mathrm{SCN}$ & $1.81 \times 10^{-5}$ \\
\hline $\mathrm{PEO} / \mathrm{PVP} / 25 \mathrm{wt} \% \mathrm{NH}_{4} \mathrm{SCN}$ & $1.36 \times 10^{-6}$ \\
\hline
\end{tabular}

\section{Conductance spectra}

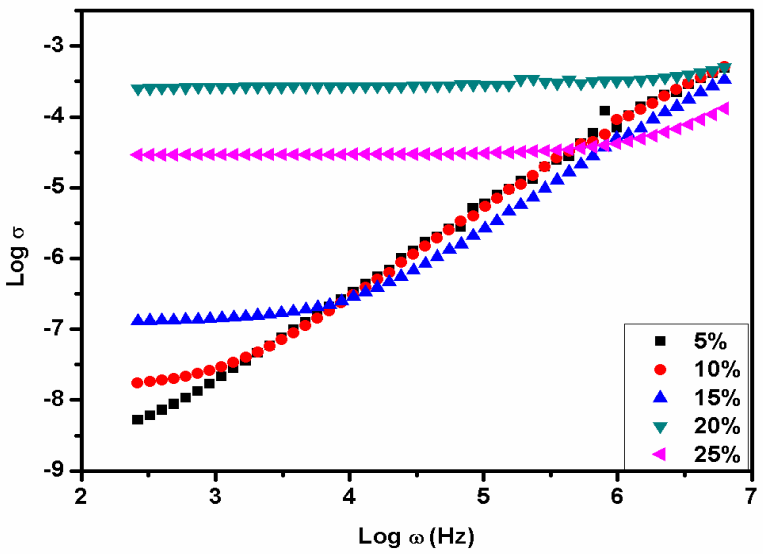

Fig. 4. Conductance spectra for PEO:PVP: $\mathrm{NH}_{4} \mathrm{SCN}$ BPEs.

Fig. 4. shows the conductance spectra of various wt $\%$ of $\mathrm{NH}_{4} \mathrm{SCN}$ doped PEO:PVP polymer blend. The conductance spectra of prepared polymers consist of two distinct regions. Due to the bulk relaxation phenomena the spike is obtained. By connecting the plateau region to the $\mathrm{Y}$ axis $\mathrm{DC}$ conductivity is calculated. $20 \mathrm{wt} \%$ of ammonium thiocyanate mixed system shows higher conductivity of $1.81 \times 10^{-5} \mathrm{~S} / \mathrm{cm}$ at $303 \mathrm{~K}$. For $25 \mathrm{wt} \%$ of ammonium thiocyanate doped system, the ionic conductivity again decreases because of aggregation of salt at higher concentration.

\section{Dielectric constant and Dielectric loss}

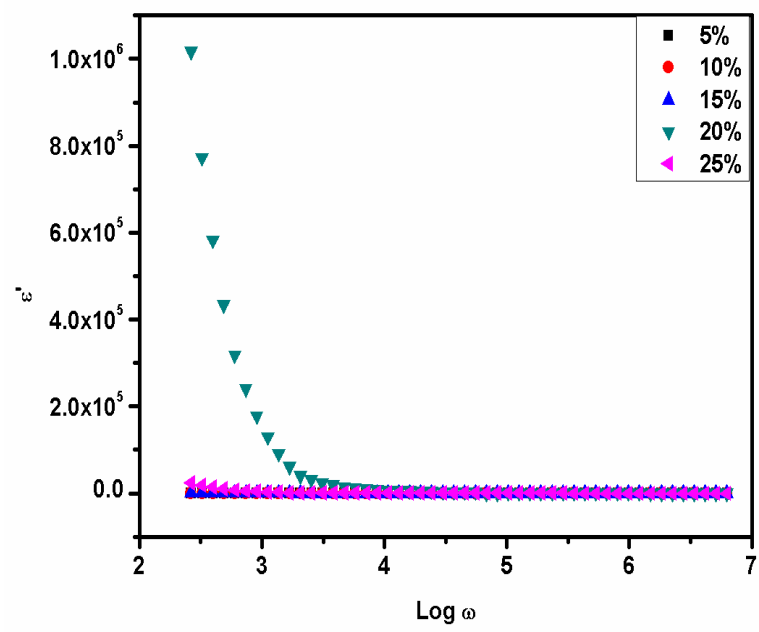

Fig. 5a. Dielectric constant for $\mathrm{PEO} / \mathrm{PVP} / \mathrm{NH}_{4} \mathrm{SCN}$ polymer blends.

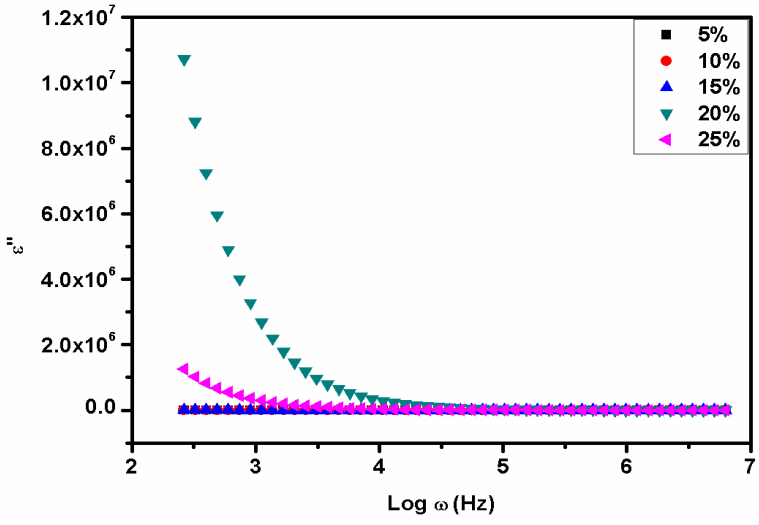

Fig. 5b. Dielectric loss for PEO/PVP/NH4SCN polymer blends.

In polymer electrolytes, dielectric constant, dielectric loss and ion conduction are very important. Reduces ion-ion interaction and also slow crystal formations are leads the high dielectric constant. Fig. 5a. Shows the dielectric constant for various wt\% of NH4SCN doped to the PEO:PVP polymer matrix. From the figure, Initial the dielectric constant has high, when applied frequency increases, the dielectric constant has been decreased, at higher frequency it shows constant. Figure $5 \mathrm{~b}$ shows the variation of dielectric loss with different frequencies with different compositions. The relation between dielectric loss and conductivity expressed as,

$$
\varepsilon^{\prime \prime}=\sigma \omega
$$

The maximum dielectric loss is obtained for the higher conductivity sample.

\section{CONCLUSION}

Different wt.\% of ammonium thiocyanate $\left(\mathrm{NH}_{4} \mathrm{SCN}\right)$ doped PEO:PVP BPEs are prepared by simple solution casting. The structural confirmations are confirmed by XRD. In XRD, pure PEO peaks are reduced due to blending and adding ammonium thiocyanate salt. The maximum crystalline nature is reduced for $20 \mathrm{wt} \%$ of $\mathrm{NH}_{4} \mathrm{SCN}$ doped PEO/PVP BPEs. Functional groups present in the polymer electrolytes are confirmed by FTIR. The conductivity is obtained at $1.81 \times 10^{-5}$ $\mathrm{S} / \mathrm{cm}$ for $20 \mathrm{wt} \%$ of $\mathrm{NH}_{4} \mathrm{SCN}$ doped PEO/PVP polymer electrolyte.

\section{ACKNOWLEDGMENT}

The authors acknowledge the management of Kalasalingam Academy of Research and Education, Krishnankoil-626126, for providing research facilities with research fellowship.

\section{REFERENCES}

1. J.M. Tarascon, M. Armand. (2001) Issues and challenges facing rechargeable lithium batteries, Nature, 414, 359-367.

2. D. Zhang, R. Li, T. Huang, A. Yu. (2010) Novel composite polymer electrolyte for lithium air batteries, J. Power Sources, 195, 1202-1206.

3. J.A. Lee, J.Y. Lee, M.H. Ryou, G.B. Han, J.N. Lee, D.J. Lee, J.K. Park, Y.M. Lee. (2011) Anion receptor-coated separator for lithium-ion polymer battery, J. Solid State Electrochem., 15, 753-757. 
4. N. Vijaya, S. Selvasekarapanian, S. Karthikeyan, M. Prabu, N. Rajeswari, C. Sanjeeviraja. (2013) synthesis and characterization of proton conducting polymer electrolyte based on poly ( $\mathrm{N}$-vinyl pyrrolidone, J. Appl. Polym. Sci. (2013), 127, 1538-1543.

5. F. Arbi, A. Mourad. (2014), conductivity and dielectric relaxation in various polyvinyl alcohol/ammonium salt composites, Polym. Sci. Ser. A, 56, 907-916.

6. C.S. Ramya, S. Selvasekarapandian, T. Savitha, G. Hirankumar, R. Baskaran, M. S. Bhuvaneswari, P. C. Angelo. (2006) Conductivity and thermal behavior of proton conducting polymer electrolyte based on poly (N-vinyl pyrrolidone, Eur. Polym. J., 42, 2672.

7. M. Hema, S. Selvasekerapandian, A. Sakunthala, D. Arunkumar, H. Nithya. (2008) Structural, vibrational and electrical characterization of PVA-NH4Br polymer electrolyte system, J. Phys. B, 403, 2740.

8. S. Selvalakshmi, N. Vijaya, S. Selvasekarapandian, M. Premalatha. (2017) Biopolymer agar-agar doped with $\mathrm{NH}_{4} \mathrm{SCN}$ as solid polymer electrolyte for electrochemical cell application, J. Appl. Polym. Sci., 2017, 44702.

9. M. Muthuvinayagam,C. Gopinathan, N. Rajeswari, S Selvasekarapandian, C. Sanjeeviraja. (2013) Proton conducting polymer electrolytes based on PVdF-PVA with $\mathrm{NH}_{4} \mathrm{NO}_{3}$, J. Polymer Eng., 33(4) 315-322.

10. M. Muthuvinayagam, C. Gopinathan. (2014) Synthesis and Characterization of Novel Proton Conducting Polymer Blend Electrolytes, Polymer-Plastics Technology and Engineering, 53 (13) 1333-1338.

11. M. Muthuvinayagam, C. Gopinathan. (2015) Characterization of proton conducting polymer blend electrolytes based on PVdF-PVA, Polymer 68, 122-130.

12. R.F. Bhajantri, V. Ravindrachary, B. Poojary, A. Ismayil Harisha, V. Crasta. (2009) Studies on fuorescent PVA+PVP+MPDMAPP composite films, Polym. Eng. Sci. 49:903-909.

13. M.A.F. Basha. (2010) Magnetic and optical studies on polyvinylpyrrolidone thin films doped with rare earth metal salts, Polymer J. 42, 728-734.

14. K. Kiran Kumar, M. Ravi, Y. Pavani, S. Bhavani, A. K. Sharma, V.V.R . Narasimha Rao. (2012) Electrical conduction mechanism in $\mathrm{NaCl}$ complexed PEO/PVP polymer blend electrolytes, Journal of Non-Crystalline Solids, 358, 3205-3211.

15. Sharanappa Chapi, S. Raghu, H. Devendrappa. (2016) Enhanced electrochemical, structural, optical, thermal stability and ionic conductivity of (PEO/PVP) polymer blend electrolyte for electrochemical applications, Ionics, 22 (6), 803-814.

16. Sireerat Intarakamhang, preparation, Characterization and molecular modeling of Poly (ethylene oxide)/Poly (vinyl pyrrolidone) Montmorillonite Nanocomposite solid electrolytes. Thesis adviser: Asst.prof. Visit Vao-Soongnern, ISBN 974-533-520-7, 2005, 54.

17. N.M. Zain and A.K. Arof, Structural and electrical properties of poly (ethylene oxide)-cadmium sulphate complexes, Mater. Sci. Eng. B, 52 (1) (1998) 40-46.

18. Ch.V. Subba Reddy, A.-P. Jin, Q.-Y. Zhu, L.-Q. Mai, W. Chen, Preparation and characterization of $(\mathrm{PVP}+\mathrm{NaClO} 4)$ electrolytes for battery applications, Eur. Phys. J. E. 19 (2006) 471-476.

19. A. Day, S. Karan, S.K. De, Effect of nanofillers on thermal and transport properties of Potassium iodide-polyethylene oxide solid polymer electrolyte, Solid state chomm. 149 (2009) 1282-1287.

20. K. Kiran Kumar, M. Ravi, Y. Pavani, S. Bhavani, A.K. Sharma, V.V.R. Narasimha Rao. (2011) Investigations on the effect of complexation of $\mathrm{NaF}$ salt with polymer blend (PEO/PVP) electrolytes on ionic conductivity and optical energy band gaps, Physica B, 406 (9), 1706-1712.

21. In: D.A. Burns, E.W. Clurczak (Eds.), Hand book of near-infrared analysis, Practical Spectroscopy Series, volume 13, Marcel Dekker, Inc., New York, 1992, p. 393

22. M. Jamal, G. Venugopal, M. Shareefuddin, M.N. Chary, "Sodium ion conducting glasses with mixed glass formers $\mathrm{NaI}-\mathrm{Na}_{2} \mathrm{O}-\mathrm{V}_{2} \mathrm{O}_{5}-\mathrm{B}_{2} \mathrm{O}_{3}$ : application to solid state battery", Mater. Let., 39, 28-32.

23. R. Manjuladevi, M. Thamilselvan, S. Selvasekarapandian, R. Mangalam, M. Premalatha, S. Monisha. (2017) Mg-ion conducting blend polymer electrolyte based on poly(vinyl alcohol)- poly (acrylonitrile) with magnesium perchlorate, Solid State Ionics, 308 90-100.

\section{AUTHORS PROFILE}

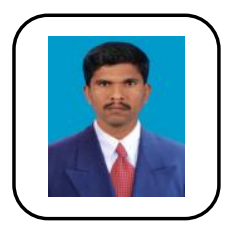

Dr. M. Muthuvinayagam is an Associate professor in the Department of Physics, School of Advanced sciences at Kalasalingam Academy of Research and Education, India. He obtained $\mathrm{PhD}$ in the area of polymer science from Madurai Kamaraj University at 2015 and M.Sc and B.Sc from Ayya Nadar Janaki Ammal college sivakasi. He has more experience in the polymer electrolyte for device application. He has published more than ten peer-review research articles in journals.

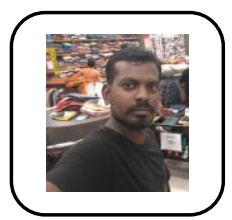

Mr. K. Sundaramahalingam is a Research scholar in the Department of Physics, School of Advanced Sciences at Kalasalingam Academy of Research and Education, India. He is doing his $\mathrm{PhD}$ in the area of polymer electrolyte for battery applications. He has obtained M.Sc Degree in Physics at Ayya Nadar Janaki Ammal College, sivakasi and B.Sc. Degree in physics from Arulmigu Kalasalingam college of Arts and Science at Krishnankoil. He has published five peer-review research articles.

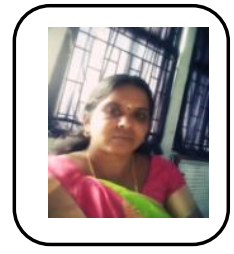

Dr. D. Vanitha is an Assistant Professor in the Department of Physics, School of Advanced Sciences at Kalasalingam Academy of Research and Education, India. She has obtained Ph.D. in the area of X-ray crystallography and Polymer Science from Kalasalingam Academy of Research and Education in 2016 and also received her M.Phil. and M.Sc. Degree in physics from Madurai Kamaraj University. She has expertise in the areas of Crystallography and Polymer Science. She has published more than ten peer-review research articles in journals of international repute besides ten more as proceedings.

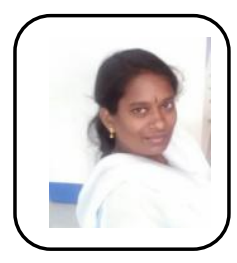

Dr. M. Vahini is a research scholar in the Department of Physics, School of Advanced sciences at Kalasalingam Academy of Research and Education, India. She obtained $\mathrm{PhD}$ in the area of polymer science from Kalasalingam Academy of Research and education at 2019 and M.Sc in Ayya Nadar Janaki Ammal college sivakasi and B.Sc at Sri Kaliswari college sivaksi. She has more experience in the polymer electrolyte for device application. She has published around seven peer-review research articles in journals. 